\title{
Aktivitas Antimikroba Ekstrak N Heksana dan Etil Asetat Kulit Ranting Sakit Sengon (Falcataria moluccana) Terhadap Enterobacteriaceae
}

\author{
Ajeung Dewi Firdausia ${ }^{1}$, Siti Yesi H.Y ${ }^{1}$, Tari P Damayanti ${ }^{1}$, Alfi Rumidatul ${ }^{2}$, \\ Feldha Fadhila ${ }^{1}$, Yayan Maryana ${ }^{3}$ \\ ${ }^{1}$ Jurusan Teknologi Laboratorium Medik Institut Kesehatan Rajawali \\ ${ }^{2}$ Sekolah Ilmu dan Teknologi Hayati ITB \\ ${ }^{3}$ Prodi Farmasi Politeknik Meta Industri
}

\begin{abstract}
Abstrak
Infeksi mikroorganisme patogen merupakan salah satu masalah dalam dunia kesehatan. Penggunaan zat antimikroba merupakan salah satu cara mengendalikannya. Namun, mikroorganisme telah mengalami banyak resisten terhadap beberapa antimikroba yang ada saat ini, sehingga memerlukan zat antimikroba yang baru untuk dapat dikendalikan. Salah satunya adalah dengan memanfaatkan tanaman Sengon (Falcataria moluccana). Pemanfaatan tanaman Sengon yang terserang penyakit diharapkan dapat menjaga kelestarian dari tanaman ini. Tujuan penelitian ini untuk mengetahui kemampuan ekstrak kulit sakit sengon dengan pelarut n- heksana dan etil asetat dalam menghambat pertumbuhan Enterobacteriaceae, S. aureus dan C. albicans. Desain penelitian yang digunakan adalah deskriptif eksperimental dengan metode uji aktivitas antimikroba difusi agar teknik Kirbybauer. Pada penelitian ini ekstrak kulit ranting sakit sengon dengan pelarut n-heksana dapat menghambat pertumbuhan pada konsentrasi optimum masing-masing $11 \mathrm{mg} / \mathrm{L}$ terhadap $S$. dysentriae dengan terbentuknya zona bening sebesar $5 \mathrm{~mm}, E$. coli sebesar $1 \mathrm{~mm}, P$. mirabilis sebesar $5 \mathrm{~mm}$ dan untuk C. albicans membentuk zona bening sebesar $6 \mathrm{~mm}$. Sedangkan, ekstrak kulit ranting sakit sengon dengan pelarut etil asetat dapat menghambat pertumbuhan pada konsentrasi optimum $11 \mathrm{mg} / \mathrm{L}$ terhadap $S$. dysentriae dengan terbentuknya zona bening sebesar 3,3 $\mathrm{mm}$. Perlu dilakukan penelitian lebih lanjut dengan meningkatkan konsentrasi ekstrak untuk mengidentifikasi konsentrasi terendah ekstrak yang dapat menghambat pertumbuhan mikroba secara maksimal.
\end{abstract}

Kata Kunci : Falcataria moluccana, Enterobacteriaceae, Staphylococcus aureus, Candida albicans

\section{Antimicrobic Activity Of N Hexana And Etil Acetate Extract of Leather Twig Sick Sengon (Falcataria moluccana)AGAINST Enterobacteriaceae}

\begin{abstract}
Infection with pathogenic microorganisms is one of the health problems. The use of antimicrobial substances is one way to control it. However, microorganisms have developed resistance to some of the currently available antimicrobials, thus requiring new antimicrobial agents to be controlled. One of them is by utilizing the Sengonplant (Falcataria moluccana). Utilization of diseased Sengon plants is expected to maintain the sustainability of this plant. The purpose of this study was to determine the ability of sengon skin extract with nhexane and ethyl acetate as solvents in inhibiting the growth of Enterobacteriaceae, S. aureus and C. albicans. The research design used was descriptive experimental with the Kirby-bauer technique of agar diffusion antimicrobial activity test method. In this study, the bark extract of sengon with n-hexane as a solvent could inhibit growth at the optimum concentration of $11 \mathrm{mg} / \mathrm{L}$ each against $S$. dysentriae with the formation of a clear zone of $5 \mathrm{~mm}, E$. coli of $1 \mathrm{~mm}, P$. mirabilis of $5 \mathrm{~mm}$ and for $C$. albicans a clear zone of $6 \mathrm{~mm}$ was formed. Meanwhile, the bark extract of sengon with ethyl acetate as a solvent could inhibit growth at an optimum concentration of $11 \mathrm{mg} / \mathrm{L}$ against $S$. dysentriae with the formation of a clear zone of $3.3 \mathrm{~mm}$. Further research needs to be done by increasing the concentration of the extract to identify the lowest concentration of extract that can inhibit microbial growth maximally.
\end{abstract}

Keywords: : Falcataria moluccana, Enterobacteriaceae, Staphylococcus aureus, Candida albicans

Korespondensi: Alfi Rumidatul, Sekolah Ilmu dan Teknologi Hayati, Institut Teknologi Bandung, mobile 081221508295,e-mail alfi@sith.itb.ac.id 


\section{Pendahuluan}

Penyakit infeksi di Indonesia masih merupakan masalah kesehatan masyarakat. Manusia merupakan makhluk hidup yang paling rentan terhadap infeksi yang disebabkan oleh bakteri patogen yang ada di lingkungan. Penyakit infeksi yang masih sering terjadi di Indonesia seperti infeksi saluran pencernaan, infeksi saluran pernafasan, infeksi saluran kemih dan infeksi jamur. Menurut Nurmala et al, 2017 Pengobatan untuk mengatasi infeksi bakteri adalah antibiotik, penggunaan antibiotik yang tidak tepat dapat menimbulkan resistensi terhadap antibiotik.

Pemanfaatan bahan alam yang berasal dari tumbuhan telah lama dilakukan oleh masyarakat Indonesia untuk menangani berbagai masalah kesehatan (Purwantoro dkk, 2016). Tumbuhan memiliki banyak peranan yang penting dalam kehidupan manusia seperti penggunaan pada pengobatan secara tradisional. Salah satu tumbuhan yang diteliti kandungan bahan alam nya yaitu tanaman sengon (Falcataria moluccana).

Senyawa aktif pada tumbuhan yang memiliki potensi sebagai antibakteri termasuk dalam golongan senyawa metabolit sekunder. Menurut Fitriyah et al, 2017 Golongan senyawa metabolit sekunder terdiri dari alkaloid, flavonoid, saponin, tanin, steroid dan triterpenoid. Pada penelitian rumidatul et al. (2018), bahwa ditemukan senyawa metabolit sekunder pada kulit sakit ranting sengon yang terdiri dari senyawa fenolik, flavonoid, saponin dan tanin. Pada penelitian Eleanore (2013), Sengon memiliki kandungan senyawa metabolit sekunder yang memiliki aktivitas antimikroba, senyawa tersebut terdiri dari alkaloid, saponin, tanin dan flavonoid. Selain itu, kulit dan kayu pohon Sengon yang terinfeksi penyakit juga dapat memproduksi senyawa fenolik, flavonoid, steroid, terpenoid, alkaloid, saponin dan antioksidan. Metabolit sekunder tanaman sengon yang terserang oleh penyakit karat tumor memiliki bioaktivitas yang lebih tinggi apabila dibandingkan dengan metabolit sekunder tanaman sengon yang sehat baik sebagai antimikroba, antioksidan dan antihelmin. (Rumidatul, dkk., 2018).

Pengujian metabolit sekunder sebagai antibakteri di awali dengan ekstraksi pelarut yang bertujuan untuk menarik metabolit sekunder yang bersifat antibakteri. Pelarut yang digunakan pada penelitian ini adalah n-heksana dan etil asetat. $\mathrm{N}$ - heksana merupakan pelarut non polar sedangkan etil asetat merupakan pelarut bersifat semi polar. Menurut Fitriyah et al, 2017 jenis kepolaran pelarut akan sangat berpengaruh terhadap hasil uji senyawa non polar akan terlarut pada pelarut non polar dan senyawa semi polar akan melarutkan senyawa aktif yang bersifat semi polar juga.

Senyawa metabolit sekunder ekstrak daun Sengon tersebut memiliki aktivitas antibakteri terhadap bakteri Staphylococcus aureus dan Ecoli (Elsas, 2014). Pada penelitian ini, dilakukan pengujian aktivitas antimikroba ekstrak kulit ranting sakit sengon (Falcataria moluccana) dengan pelarut n-heksana dan etil asetat terhadap Salmonella typhi, Shigella dysenteriae, Klebsiella pneumoniae, Escherichia coli, Proteus mirabilis, Pseudomonas aeruginosa, Staphylococcus dan Candida albicans.

\section{Metode}

Penelitian ini menggunakan rancangan penelitian dekstriptif eksperimental yaitu pengujian ekstrak kulit ranting sakit Sengon yang diperoleh melalui Teknik maserasi dengan pelarut n-heksana dan etil asetat terhadap Enterobacteriaceae, S. aureus dan C. albicans dengan metode uji Kirby-Bauer.

Tempat dan waktu penelitian yaitu di Laboratorium Mikrobiologi Institut Kesehatan Rajawali Bandung pada bulan Februari 2020. Alat dan bahan yang digunakan Biakan mikroba uji, Ekstrak kulit ranting sakit Sengon dengan pelarut n-heksana dan etil asetat, Medium Nutrient Agar (NA), Medium Nutrient Broth (NB), Medium Potato Dextrose Agar (PDA), Medium Potato Dextrose Broth (PDB), Larutan standar Mc. Farland 0,5\%, Akuades, Alkohol 96\%, Autoklaf, Kertas cakram, Batang Pengaduk, Cawan Petri, Inkubator, Laminar air flow, Mikroskop, Oven, Neraca analitik dan Spektrofotometer UV dengan panjang gelombang $600 \mathrm{~nm}$.

Metode yang digunakan yaitu metode Kirby-Bauer yaitu pengujian aktivitas antimikroba dengan cara meletakkan kertas cakram berdiameter $6 \mathrm{~mm}$ yang telah ditetesi ekstrak kulit ranting sakit Sengon pada permukaan medium NA yang telah ditanami mikroba uji.

\section{Hasil}

Penelitian dimulai dengan melakukan identifikasi mikroba uji yaitu dengan pewarnaan Gram dan pengamatan secara mikroskopis. Hasil penelitian dapat dilihat pada 
tabel 1.

Tabel.1 Identifikasi Mikroba Uji

\begin{tabular}{|c|c|c|}
\hline $\begin{array}{c}\text { Mikroba } \\
\text { Uji }\end{array}$ & $\begin{array}{l}\text { Morfologi } \\
\text { Koloni }\end{array}$ & Motfologi Sel \\
\hline C. albicans & $\begin{array}{l}\text { Koloni kecil, } \\
\text { berbentuk bulat } \\
\text { dengan } \\
\text { permukaan } \\
\text { mucoid, } \\
\text { berwarnaputih } \\
\text { dengan tepian } \\
\text { halus danrata } \\
\end{array}$ & $\begin{array}{c}\text { Berbentuk } \\
\text { blastoconodia, } \\
\text { berwarna ungu, } \\
\text { Gram positif }\end{array}$ \\
\hline $\begin{array}{c}\text { Salmonella } \\
\text { typhi }\end{array}$ & $\begin{array}{l}\text { Koloni sedang, } \\
\text { berbentuk } \\
\text { bulat, elevasi } \\
\text { cembung } \\
\text { dengan } \\
\text { permukaan } \\
\text { halus,berwarna } \\
\text { putih/translucen }\end{array}$ & $\begin{array}{c}\text { Berbentuk } \\
\text { basil tunggal, } \\
\text { berwarna } \\
\text { merah, Gram } \\
\text { Negatif }\end{array}$ \\
\hline $\begin{array}{c}\text { Klebsiella } \\
\text { pneumoniae }\end{array}$ & $\begin{array}{l}\text { Koloni sedang, } \\
\text { berbentuk bulat } \\
\text { beraturan, } \\
\text { elevasi } \\
\text { cembung } \\
\text { dengan } \\
\text { permukaan } \\
\text { mucoid, } \\
\text { berwarna putih } \\
\text { susu/buram }\end{array}$ & $\begin{array}{l}\text { Berbentuk } \\
\text { basil pendek } \\
\text { berpasangan, } \\
\text { berwarna } \\
\text { merah, Gram } \\
\text { Negatif }\end{array}$ \\
\hline $\begin{array}{c}\text { Shigella } \\
\text { dysenteriae }\end{array}$ & $\begin{array}{c}\text { Koloni kecil, } \\
\text { berbentuk bulat } \\
\text { beraturan, } \\
\text { elevasi } \\
\text { cembung } \\
\text { dengan } \\
\text { permukaan } \\
\text { halus, berwarna } \\
\text { putih } \\
\text { bening/transluc } \\
\text { ent }\end{array}$ & $\begin{array}{l}\text { Berbentuk } \\
\text { basil pendek } \\
\text { tunggal, } \\
\text { berwarna } \\
\text { merah, Gram } \\
\text { Negatif }\end{array}$ \\
\hline $\begin{array}{c}\text { Escherchia } \\
\text { coli }\end{array}$ & $\begin{array}{c}\text { Koloni kecil, } \\
\text { berbentuk } \\
\text { bulat } \\
\text { beraturan, } \\
\text { elevasi } \\
\text { cembung } \\
\text { dengan } \\
\text { permukaan } \\
\text { halus, berwarna } \\
\text { putih } \\
\text { susu/buram. }\end{array}$ & $\begin{array}{l}\text { Berbentuk } \\
\text { basil pendek } \\
\text { tunggal, } \\
\text { berwarna } \\
\text { merah, Gram } \\
\text { Negatif }\end{array}$ \\
\hline $\begin{array}{l}\text { Proteus } \\
\text { mirabilis }\end{array}$ & $\begin{array}{l}\text { Koloni sedang } \\
\text { berbentuk } \\
\text { bulat,cembung }\end{array}$ & $\begin{array}{l}\text { Berbentuk } \\
\text { basil pendek, } \\
\text { berkelompok, }\end{array}$ \\
\hline
\end{tabular}

$$
\text { , tepian tidak }
$$$$
\text { rata,menjalar }
$$

dan berwarna

merah, Gram

Negatif

\begin{tabular}{ccc}
$\begin{array}{c}\text { Pseudomon } \\
\text { as }\end{array}$ & $\begin{array}{c}\text { Koloni kecil, } \\
\text { berbentuk } \\
\text { beruginosat, } \\
\text { konsistensi } \\
\text { kasar, tepian } \\
\text { tidak rata, } \\
\text { menjalar }\end{array}$ & $\begin{array}{c}\text { Berbentuk } \\
\text { basil, rantai } \\
\text { pendek, } \\
\text { berwarna } \\
\text { merah, Gram } \\
\text { Negatif }\end{array}$ \\
& & \\
Staphylococ & $\begin{array}{c}\text { Koloni kecil, } \\
\text { berbentuk } \\
\text { bus aureus }\end{array}$ & $\begin{array}{c}\text { Berbentuk } \\
\text { kokus, }\end{array}$ \\
& $\begin{array}{c}\text { konsistensi } \\
\text { bergelombol } \\
\text { (seperti buah }\end{array}$ \\
& halus, tepian & anggur), dan \\
rata, tidak & berwarna ungu, \\
menjalar & Gram Positif \\
\hline
\end{tabular}

Penelitian dilanjutkan dengan pembuatan kurva pertumbuhan mikroba yang bertujuan untuk menentukan waktu pengambilan koloni yang optimal, yaitu pada fase logaritmik mikroba uji. Pada fase ini, mikroba tumbuh dan membelah pada kecepatan maksimum dan cocok untuk pengujian antimikroba. Hal ini dikarenakan waktu tersebut menunjukkan masing-masing mikroba uji sedang aktif melakukan pembelahan sel dengan laju yang konstan, aktivitas metabolic konstan serta keadaan pertumbuhan yang seimbang (Hamidah MN, dkk., 2019). Setiap bakteri memiliki laju pertumbuhan yang berbeda-beda disetiap fasenya. Perbedaan tersebut disebabkan oleh kemampuan bakteri yang berbeda-beda dalam berkembang biak, tergantung pada medium pertumbuhan, $\mathrm{pH}$, suhu, kemampuan membelah, kemampuan bertahan hidup, waktu inkubasi, kandungan enzim, kandungan metabolit sekunder dan nutrisi yang ada. Faktor pertumbuhan bakteri bergantung pada $\mathrm{pH}$ dan suhu. Suhu optimum pertumbuhan bakteri adalah $37^{\circ} \mathrm{C}$ (Iqlima D, dkk., 2017). Hasil kurva pertumbuhan mikroba uji dapat dilihat pada Gambar 1.

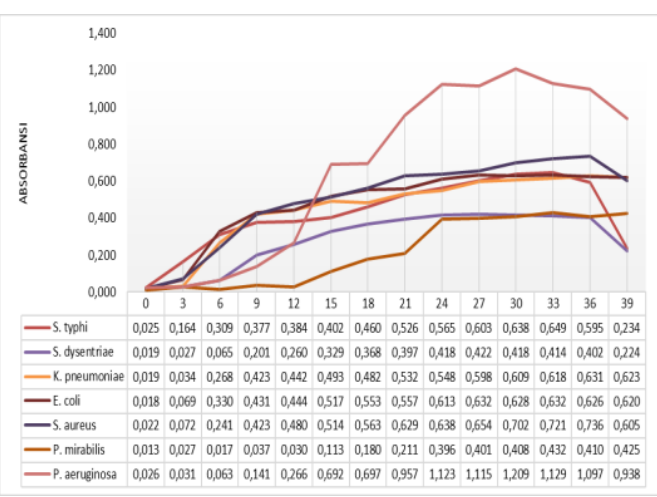


Gambar 1. Kurva Pertumbuhan Bakteri dengan panjang gelombang 600 nm.

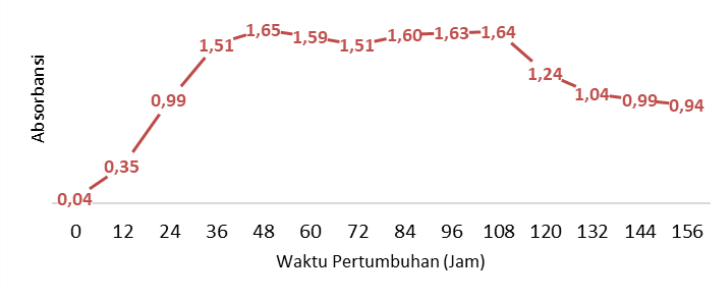

Gambar 2. Kurva Pertumbuhan C. albicans dengan panjang gelombang 600 nm.

Hasil kurva pertumbuhan menunjukkan fase $\log S$. typhi, S. dysentriae, dan E. coli berada pada jam ke $4-24$, sedangkan $K$. pneumonia berada pada jam ke- $4-27, P$. aeruginosa pada jam ke- $6-24, P$. mirabilis jam ke- $15-24, S$. aureus pada jam ke- $3-21$. Fase stasioner $S$. typhi dan $S$. dysentriae berada pada jam ke- $25-36, K$. pneumonia pada jam ke- 28 - 39, E. coli pada jam ke- $25-39, P$. aeruginosa pada jam ke- 27 - 33, P. mirabilis pada jam ke- 27 - 39, S. aureus pada jam ke$24-36$

Waktu pengambilan koloni untuk pengujian aktivitas antimikroba $S$. typhi dan $K$. pneumonia dilakukan pada jam ke- $18, S$. dysentriae dan E. coli pada jam ke- 15, $P$. aeruginosa pada jam ke- $12, P$. mirabilis pada jam ke- 21, $S$, aureus pada jam ke- 6 . Sedangkan hasil kurva pertumbuhan $C$. albicans antara lain fase lag berada pada jam ke-0 - 6, kemudian fase log mulai dari jam ke$12-60$, fase stasioner berada pada jam ke-66 90 dan fase kematian mulai terlihat pada jam ke-96. Adapun waktu pengambilan koloni untuk perlakuan uji aktivitas antibakteri dilakukan pada jam ke- 36 .

Berdasarkan hasil uji aktivitas antimikroba ekstrak kulit kayu ranting sakit sengon dengan pelarut $n$-heksan dengan rentang konsentrasi 9-11 mg/L terhadap mikroba uji S.dysentriae, K. pneumoniae, E.coli, S.thypi, P. mirabilis, $P$. aeruginosa, $S$. aureus dan $C$. albicans yaitu terbentuknya zona bening pada media $P$. mirabilis di sekitar cakream dengan ekstrak $9 \mathrm{mg} / \mathrm{L}$ - $11 \mathrm{mg} / \mathrm{L}$, terbentuknya zona bening pada media C.albicans di sekitar cakram dengan ekstrak 10,5 mg/L - $11 \mathrm{mg} / \mathrm{L}$, terbentuknya zona bening pada media S.dysentriae di sekitar cakram dengan ekstrak $11 \mathrm{mg} / \mathrm{L}$, terbentuknya zona bening pada media E.coli di sekitar cakram dengan ekstrak 11 $\mathrm{mg} / \mathrm{L}$, dan tidak terbentuknya zona bening pada media S.typhi, S. aureus, P. aeruginosa dan K.pneumoniae. Sementara itu, hasil uji aktivitas antimikroba ekstrak dengan pelarut etil asetat terhadap S.dysentriae yaitu terbentuknya zonna bening di sekitar cakram dengan ekstrak $9 \mathrm{mg} / \mathrm{L}-11 \mathrm{mg} / \mathrm{L}$ dan tidak terbentuknya zona bening pada media $K$. pneumonia dan E. coli. Pada pengujian $C$. albicans menggunakan ekstrak kulit ranting sakit sengon dengan pelarut $\mathrm{n}$ heksana zona bening yang terbentuk sebesar $4 \mathrm{~mm}$ pada konsentrasi ekstrak 10,5 $\mathrm{mg} / \mathrm{dL}$ dan $6 \mathrm{~mm}$ pada konsentrasi ekstrak 11 $\mathrm{mg} / \mathrm{dL}$. Zona bening yang terbentuk lebih besar dibandingkan dengan pengujian $S$. dysentriae dimana zona bening yang terbentuk sebesar 5 $\mathrm{mm}$ pada konsentrasi ekstrak $11 \mathrm{mg} / \mathrm{dL}$. Hal ini dikarenakan perbedaan pada struktur dinding sel $S$. dysentriae yang sulit ditembus zat metabolik sekunder ekstrak sengon.

Pembahasan

Berdasarkan hasil pengamatan S. typhi tampak berwarna merah (Gram negatif) dengan bentuk sel batang tunggal. S. dysentriae dan $E$. coli tampak berwarna merah (Gram Negatif) dengan bentuk sel batang pendek. $K$. pneumonia dan $P$. aeruginosa tampak berwarna merah (Gram negatif) dengan bentuk sel batang pendek berpasangan. $P$. mirabilis tampak berwarna merah (Gram negatif) dengan bentuk sel batang pendek berkelompok. Bakteri Gram negatif berwarna merah sebab kompleks warna tersebut larut pada saat pemberian larutan alkohol, sehingga mengambil warna merah safranin (Nurhidayati S, dkk., 2015)

S. aureus tampak berwarna ungu (Gram positif) dengan bentuk sel bulat bergerombol seperti buah anggur. Bakteri Gram positif setelah dilakukan proses pengecatan Gram akan menghasilkan warna ungu ketika diamati dibawah mikroskop dikarenakan dinding sel bakteri Gram positif tersusun atas peptidoglikan yang tebal sehingga mampu mempertahankan zat warna kristal violet meskipun telah diberikan larutan pemucat (Hamidah MN, dkk., 2019). Sedangan pada C. albicans tampak berwarna ungu (Gram positif) dengan bentuk sel blastoconodia (Kayser FH, dkk., 2005).

Setiap bakteri memiliki laju pertumbuhan yang berbeda-beda disetiap fasenya. Perbedaan tersebut disebabkan oleh kemampuan bakteri yang berbeda-beda dalam berkembang biak, tergantung pada medium pertumbuhan, $\mathrm{pH}, \quad$ suhu, kemampuan membelah, kemampuan bertahan hidup, waktu inkubasi, kandungan enzim, kandungan metabolit sekunder dan nutrisi yang ada. 
Faktor pertumbuhan bakteri bergantung pada $\mathrm{pH}$ dan suhu. Suhu optimum pertumbuhan bakteri adalah $37^{\circ} \mathrm{C}$ (Iqlima D, dkk., 2017). Penelitian pengujian aktivitas antimikroba ektrak kulit ranting sakit Sengon dengan pelarut n-heksana dan etil asetat terhadap pertumbuhan Enterobacteriaceae, S. aureus, dan C. albicans dengan metode Kirby-bauer bertujuan untuk mengetahui apakah ekstrak kulit ranting sakit Sengon mempunyai aktivitas antimikroba.

Berdasarkan literatur E. coli mengalami fase lag pada jam ke-0 hingga jam ke 2, fase log jam ke-4 hingga jam ke-15 (Handayani, P, 2015). S. dysenteriae mengalami fase lag pada jam ke-0 hingga jam ke-4, fase log jam ke-5 hingga jam ke-15 (Rahmawati M, 2015). $K$. pneumoniae mengalami fase lag pada jam ke-0 hingga jam ke-2, fase log dimulai dari jam ke10 (Fauziah PN, 2013). P. Aeruginosa mengalami fase lag dimulai pada jam ke-0 hingga jam ke-4. Fase eksponensial berlangsung cepat yang terjadi pada jam ke- 8 sampai jam ke-14. Fase stasioner terjadi pada jam ke-16 hingga jam ke-24 setelah itu fase kematian terjadi pada jam ke-26 (Khoiroh Z, 2014). Fase adaptasi $S$. aureus menunjukkan pola pertumbuhan yang terjadi pada jam ke-0. Fase log terjadi pada jam ke-4 hingga jam ke12. Fase stasioner terjadi pada jam ke-16 sampai jam ke-24. Fase kematian terjadi pada jam ke-28 (Rahmawati D, 2017). S. typhi menunjukkan fase lag terjadi pada jam ke- 0 sampai jam ke-9 dan fase log pada jam ke- 10 sampai jam ke- 19 (Pratiwi AE, 2015).

Data pada penelitian ini adalah parametrik dikarenakan data dihasilkan dari pengamatan visual terhadap zona bening yang terbentuk di sekitar kertas cakram yang telah ditetesi dengan ekstrak kulit ranting sakit Sengon yang dinyatakan dalam rasio.

Pengukuran dilakukan menggunakan jangka sorong dan diameter zona bening dinyatakan dalam satuan $\mathrm{mm}$ (millimeter). Hasil dapat dilihat pada Gambar 3.

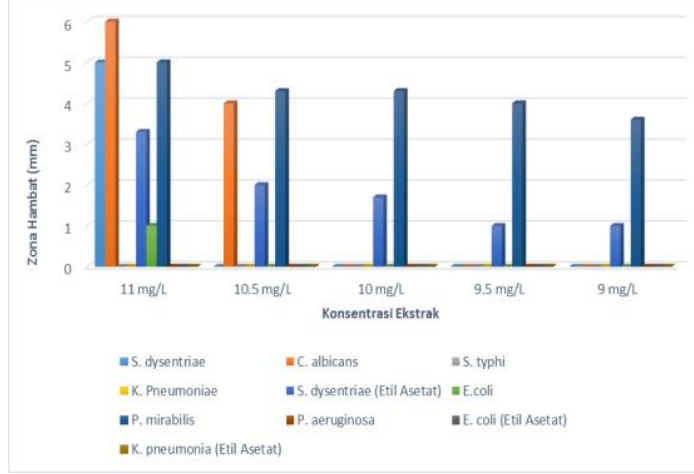

Gambar 3. Diagram Zona Bening Mikroba
Bakteri Gram negatif memiliki struktur dinding sel yang lebih kompleks, yaitu berlapis tiga terdiri dari lapisan luar lipoprotein, lapisan tengah lipopolisakarida yang berperan sebagai penghalang masuknya bahan bioaktif antimikroba dan lapisan dalam berupa peptidoglikan dengan kandungan lipid tinggi (11-12\%) (Brook GF, dkk., 2005). Sementara itu $C$. albicans memiliki lapisan dinding sel yang lebih sederhana sehingga senyawa yang bersifat fungiastatik misalnya fenolik dapat mendenaturasi protein, yaitu kerusakan struktur tersier protein sehingga protein kehilangan sifat-sifat aslinya. Terdenaturasinya protein dinding C.albicans akan menyebabkan kerapuhan pada dinding sel tersebut sehingga mudah ditembus senyawa metabolit sekunder lain yang bersifat antimikroba (Rahman, $\mathrm{N}$ dan Aditya, R.K, 2010).

S.typhi dan K.pneumonia tidak terhambat pertumbuhannya hal ini diduga karena perbedaan struktur sel bakteri. Sel $S$. typhi terdiri atas struktur lipopolisakarida kompleks (LPS) yang menyebabkan $S$. typhi dapat terbebas dari lisis sel (Jawetz, dkk., 2010). Sedangkan $K$. pneumonia memiliki kapsul polisakarida untuk mempertahankan dirinya. Kapsul ini terdiri dari kompleks asam polisakarida yang lapisannya melindungi sel $K$. pneumonia (Qureshi M, dkk., 2014).

Zona bening yang terbentuk pada media $P$. mirabilis sebesar 5,0 mm dengan konsentrasi $11 \mathrm{mg} / \mathrm{L}$, diikuti $4,3 \mathrm{~mm}$ dengan konsentrasi $10,5 \mathrm{mg} / \mathrm{L}$ dan konsentrasi $10 \mathrm{mg} / \mathrm{L}$, terakhir 3,6 $\mathrm{mm}$ dengan konsentrasi $9 \mathrm{mg} / \mathrm{L}$. Terbentuknya zona bening pada $P$. mirabilis dikarenakan adanya kandungan senyawa metabolit sekunder dari kulit sakit ranting sengon yang berpotensi sebagai antibakteri alami yang dapat menghambat pertumbuhan bakteri seperti flavonoid, steroid, fenol, dan terpenoid. Flavonoid memiliki mekanisme kerja dalam menghambat pertumbuhan bakteri dengan terjadinya kerusakan permeabilitas dinding sel bakteri (Sulistyani, dkk., 2016). Steroid dapat menyebabkan integritas membran menurun serta morfologi membran sel berubah yang menyebabkan sel rapuh dan lisis (Rahmawati D, 2017). Fenol bekerja secara spesifik pada membran sel, mendenaturaasi protein bakteri dan memecah mebran sel (Rahmawati D, 2017). Terpenoid dapat bereaksi dengan porin (protein transmembran) pada membran luar dinding sel bakteri sehingga mengakibatkan rusaknya porin. Rusaknya porin yang merupakan pintu keluar masuknya senyawa akan mengurangi permeabilitas 
dinding sel bakteri (Amalia S, dkk., 2014).

Hasil pengujian aktivitas antimikroba terhadap $P$. aeruginosa dan $S$. aureus tidak terbentuk zona bening karena $P$. aeruginosa merupakan bakteri patogen yang sering mengalami resistensi. Bakteri ini mampu membuat mekanisme pertahanan diri karena adanya faktor intrinsik mikrobiologi yaitu plasmid (Huda M, 2016). P. aeruginosa memiliki plasmid yang merupakan sarana dalam mekanisme resistensi disebabkan adanya gen resisten yang terletak pada plasmid. Hal ini di perkuat oleh penelitian sebelumnya yang menyebutkan bahwa $P$. aeruginosa memiliki plasmid sebagai peluang yang sangat tinggi untuk mengalami resistensi (Rustini, 2017). Sedangkan $S$. aureus merupakan bakteri patogen utama penyebab supuratif infeksi yang berangsur- angsur menuju golongan bakteri yang resisten. S. aureus dapat memproduksi $\beta$ laktamase sehingga dengan mudah dapat resisten terhadap golongan antibiotik $\beta$ - laktam seperti penicillin (Boyd K, 2017). Sebagian besar bakteri yang resisten muncul akibat bakteri yang mengandung plasmid dapat menghasilkan enzim yang dapat merusak antibiotik seperti plasmid yang mengandung laktamase dapat dipindahkan dari $S$. aureus yang resisten ke jenis yang sensitif dengan cara perpindahan plasmid resisten pada saat konjugasi (Jawetz M, dkk., 2008). S. aureus juga memiliki faktor virulensi salah satunya yaitu antigen permukaan berperan dalam proses kolonisasi bakteri pada permukaan sel jaringan inang dan memegang peranan penting dalam proses penempelan antara S.aureus dengan sel epitel (Ote I, dkk., 2011).

Ekstrak kulit sakit ranting Sengon $(F$. moluccana) dengan pelarut etil asetat berpotensi menghambat pertumbuhan $S$. dysenteriae dapat terlihat dari diameter zona bening yang terbentuk setelah dilakukan 3 kali pengulangan pada konsentrasi $11 \mathrm{mg} / \mathrm{L}$ dengan diameter yang terbentuk $3,3 \mathrm{~mm}$ dan konsentrasi $9 \mathrm{mg} / \mathrm{L}$ terbentuk $1 \mathrm{~mm}$. Hal tersebut sesuai dengan literatur yang menyatakan semakin tinggi konsentrasi ekstrak, semakin banyak pula kandungan senyawa aktif berdifusi ke dalam bakteri yang dapat membunuh bakteri tersebut (Jacky, dkk., 2019).

Zona bening yang terbentuk akibat adanya senyawa yang terkandung di dalam ekstrak yang dapat menghambat pertumbuhan bakteri. Senyawa yang terkandung dalam ekstrak kulit sakit ranting Sengon ( $F$. moluccana) dengan pelarut etil asetat sesuai dengan uji fitokimia menujukan bahwa senyawa terpenoid, steroid, flavonoid dan fenolik terdapat pada ekstrak etil asetat (Rahmawati D, 2017). Mekanisme kerja flavonoid sebagai antibakteri yaitu dengan cara menghambat fungsi membran sel dalam membentuk senyawa kompleks dengan protein ekstraseluler dan terlarut sehingga merusak membran sel bakteri (Jacky, dkk., 2019). Fenol yang bersifat lipofil akan merusak membran mikroba, adanya kemampuan untuk mendenaturasi protein (Jacky, dkk., 2019). Steroid dapat berinteraksi dengan membran fosfolipid sel yang bersifat permeabel terhadap senyawa lipofilik sehingga menyebabkan integritas membran yang menurun, morfologi membran sel berubah dan akhirnya menyebabkan membran sel rapuh dan lisis (Jacky, dkk., 2019). Mekanisme terpenoid sebagai antibakteri adalah bereaksi dengan porin (protein transmembran) pada membran luar dinding sel bakteri, membentuk ikatan polimer yang kuat sehingga mengakibatkan rusaknya porin (Yaqin A, 2014).

Berdasarkan hasil penelitian yang telah dilakukan, diperoleh kesimpulan bahwa Ekstrak kulit kayu ranting sakit sengon dengan pelarut n-heksana dapat menghambat S.dysentriae (5 $\mathrm{mm})$, C.albicans $(6 \mathrm{~mm})$, P. mirabilis $(5 \mathrm{~mm})$ E.coli $(1 \mathrm{~mm})$ dengan konsentrasi ekstrak optimum $11 \mathrm{mg} / \mathrm{L}$, sedangkan ekstrak kulit kayu ranting sakit sengon dengan pelarut etil asetat dapat menghambat $S$. dysentriae (3,3 $\mathrm{mm})$ dengan konsentrasi ekstrak optimum 11 $\mathrm{mg} / \mathrm{L}$ dan tidak menghambat pertumbuhan $E$. coli dan $K$. pneumoniae.

Adapun saran dalam penelitian ini yaitu melakukan pemurnian dan identifikasi senyawa yang terdapat pada esktrak kulit sakit ranting sengon.

\section{Daftar Pustaka}

Amalia S, Wahdaningsih S, Untari EK. (2014). Antibacterial Activity Testing of N- Hexane Fraction of Red Dragon (Hylocereus polyrhizus Britton \& Rose) Fruit Peel on Staphylococcus aureus ATCC 25923. Traditional Medicine Journal;19(2):89- 94.

Boyd K. (2017). Back to the basics: Communityacquired Pneumonia In Children. Pediatr Ann; 46 (7):257-261.

Brooks GF, Janet SB, Stephen AM. Jawetz, Melnick, \& Adelberg's. (2005). Mikrobiologi Kedokteran Buku 1. EGC: Jakarta 
Eleanore Y. (2013). Analisis fitokimia dan aktivitaqs antioksidan ekstrak daun sengon (Paraserianthes falcataria (L) Nielsen) menggunakan metode DPPH. Bogor: Fakultas Matematika dan Ilmu Pengetahuan Alam, Institut Pertanian Bogor

Fahrizal MD. (2014). Total Fenolik dan Flavonoid Serta Aktivitas Antioksidan Ekstrak Kulit Kayu Sengon (Paraserianthesfalcataria $(\mathrm{L})$.$) Bogor:$

Fakultas Matematika dan Ilmu Pengetahuan Alam Institut Pertanian Bogor.

Fauziah P.N, Nurhajati J, Chrysanti. (2013) Pengaruh laju pertumbuhan dan waktu generasi terhadap penghambatan pertumbuhan koloni klebsiella pneumoniae strain atcc 700603 , ct1538 dan s941 oleh Lactobacillus bulgaricusks1 dalam soyghurt. Jurnal Kesehatan Kartika;8(1):1-14.

Fitriyah, Mappiratu, Prismawiryanti. (2017). Uji Aktivitas Antibakteri Ekstrak Daun Tanaman Johar (Cassia siamea Lamk.) Dari Beberapa Tingkat Kepolaran Pelarut. Kovalen Jurnal Riset Kimia;3(3):242-251

Hamidah MN, Rianingsih L, dan Romadhon. (2019). Aktivitas Antibakteri Isolat Asam Laktat Dari Peda Dengan Jenis Ikan Berbeda Terhadap E.coli dan $S$. aureus. Jurnal Ilmu dan TeknologiPerikanan;1(2):11-21.

Handayani, P. (2015) Isolasi, Seleksi, Dan Uji Aktivitas Antimikroba Kapang Endofit Dari Daun Tanaman Jamblang (Syzygium Cuminil.) Terhadap Escherichia coli, Pseudomonas aeruginosa, Bacillus subtilis,Staphylococcus aureus, Candida albicans dan Aspergillus niger.Jakarta : Fakultas Kedokteran dan Ilmu Kesehatan.

Hidayah WW, Kusrini D dan Fachriyah E. (2016). Isolasi, Identifikasi Senyawa Steroid dari Daun Getih-Getihan (Rivina humilis L.) dan Uji Aktivitas sebagai Antibakteri.

Huda M. (2016) Resistensi Bakteri Gram Negatif Terhadap Antibiotik Di UPTD Balai Laboratorium Kesehatan Lampung Tahun 2012-2014. Jurnal Analis Kesehatan 2016; 5(1):494-503.

Iqlima D, Ardiningsih P, dan Wibowo MA. (2017). Aktivitas Antibakteri Isolat Bakteri Endofit B2d Dari Batang Tanaman Yakon (Smallanthus sonchifolius (Poepp. \& Endl.) H. Rob.) Terhadap Bakteri Staphylococcus aureus dan Salmonella thypimurium. JKK 2017;7(1):36-43
Jauhari, L.T. (2010) Seleksi dan Identifikasi Kapang Endofit Penghasil Antimikroba Penghambat Pertumbuhan Mikroba Patogen. [Skripsi], Jakarta: Program Studi Sarjana Biologi. Fakultas Sains dan Teknologi. Universitas Islam Syarif Hidayatullah

Jawetz, Melnick, Adelberg. Mikrobiologi Kedokteran. (2008). Jakarta: Buku Kedokteran EGC

Jawetz E, Melnick \& Adelberg's. (2010). Mikrobiologi Kedokteran. Edisi 25, Jakarta: EGC.

Jacky, Putri DA, Azizah M. (2019). Uji Aktivitas Antibakteri Ekstrak Etanol Daun Pandan Wangi (Pandanus Amaryllifolius Roxb) Terhadap Bakteri Penyebab Diare. Palembang : Sekolah Tinggi Ilmu Farmasi Bhakti Pertiwi Palembang.

Kayser FH, Bienz KA, Eckert J, Zinkernagel RM. (2005). Medical microbiology. New York.Thieme.

Khoiroh Z. (2014). Bioremediasi Logam Berat Pb dalam Lumpur Lapindo Menggunakan Campuran Bakteri (Pseudomonas pseudomallei dan Pseudomonas aeruginosa). Jurnal Biologi UIN Malang 2014;1(50):1-10

Nurhidayati S, Faturrahman, dan Ghazali M. (2015) Deteksi Bakteri Patogen Yang Berasosiasi Dengan Kappaphycus alvarezii (Doty) Bergejala Penyakit Ice-Ice. Jurnal Sains Teknologi dan Lingkungan2015;1(2):24-30.

Nurmala, Virgiandhy IGN, Andiani, Liana DF. (2015). Resistensi dan Sensitivitas Bakteri terhadap Antibiotik di RSU dr. Soedarso Pontianak tahun 2011-2013. Vol-3

Ote I, Taminiau B, Duprez JN, Dizier I, and Mainil JG. (2011). Genotypic characterization by Polymerase Chain Reaction of Staphylococcus aureus isolates associated with bovine mastitis. Vet. Microbiol. 2011; 153:285-292.

Pratiwi AE. (2015). Isolasi, Seleksi dan Uji Aktivitas Antibakteri Mikroba Endofit Dari Daun Tanaman Garcinia benthami Pierre Terhadap Staphylococcus aureus, Bacillus subtilis, Escherichia coli, Shigella dysentriae, dan Salmonella typhimurium. UIN Syarif Hidayatullah. Program Studi Farmasi. Jakarta: Fakultas Kedokteran dan Ilmu Kesehatan

Purwantoro RS, Siregar HM, Sudarmono, Agusta A. (2016). Potensi Antibakteri Ekstrak Daun Lasianthus Terhadap Bakteri Pseudomonas 
aeruginosa. Jurnal Jamu Indonesia 1(3):6-11

Rahman, N dan Aditya, R.K. (2010) Uji Fungiastatik Rkstrak Daun SirihTerhadap Candida albicans. Journal of Environmental Biology; 2010: 31(1): 387-389.

Rahmawati, M. (2015) Uji Aktivitas Antimikroba Ekstrak Etanol Dan Air Rimpang Pacing (Costus Spiralis) Terhadap Bakteri Escherichia Coli, Shigella dysenteriae, Salmonella typhimurium, Bacillus subtilis, Staphylococcusauureus Serta Fungi Candida albicans. Jakarta : Fakultas Kedokteran Dan Ilmu Kesehatan Program Studi Farmasi.

Rahmawati D. (2017). Evaluasi Karakter Morfologi, Fitokimia, Genetik Sengon (Falcataria moluccana) Resisten dan Rentan Terhadap Karat Puru. Sekolah Pascasarjana Institut Pertanian Bogor; Bogor.

Ristiati NP. (2015) Uji Bioaktivitas Forbazol E Terhadap Hambatan Pertumbuhan Pada Staphylococcus aureus. Jurnal Sains dan Teknologi 2015; 4(1): 566-578.

Rumidatul A, Aryantha INP, dan Sulistyawati E. (2018). Potensi medik metabolit tanaman sengon (Falcataria moluccana) Yang Terserang Penyakit Karat Tumor. Institut Teknologi Bandung; Bandung.

Rustini. (2017). Hubungan Extended Spectrum $\beta$ laktamase, Plasmid, Var Gen blaTEM, blaCTX, dan MexAB-OprM Efflux Pump Dengan Resistensi Bakteri Pseudomonas aeruginosa. Universitas Andalas Padang; Padang.

Sulistyani, Nunung EK, Yakup, dan R. A. C. (2016). Aktivitas Antibakteri Infusa Daun Lidah Buaya (Aloe barbadensis Miller). Jurnal Penelitian Saintek 2016;12(34):120-128.

Qureshi M, Asif N, Baig S. (2014). Evaluation of Extended Spectrum $\beta$-lactamase Mediated Resistance in Escherichia coli and Klebsiella in Urinary Tract Infection at A Tertiary Care Hospital. Biomedica.

Yaqin, A. (2014) Potensi Antibakteri Ekstrak etanol, Fraksi Etanol-Air Dan Fraksi N- Heksan Ekstrak Etanol Daun Anggur (Vitis Viniferal) Terhadap Staphylococcus aureus Dan Pseudomonas aeruginosa Multiresisten. Surakarta: Fakultas Farmasi Universitas Muhammadiyah Surakarta: Surakarta 